\title{
Life Cycle Analysis of Biodiesel Blends for Aviation
}

\author{
Análisis de Ciclo de Vida de Mezclas de Biodiesel Para Aviación
}

\author{
William Evelio Rodríguez Delgado ${ }^{(1)} 1^{*}$ | Anderson Guillermo \\ Rodríguez Meléndez ${ }^{(1)}$ 1* $^{*}$ Manuel Alejandro Mayorga \\ Betancourt $\left(\mathbb{D} 1^{*}\right.$ | Javier Alejandro Bonilla Páez ${ }^{\left(\mathbb{D} 1^{*}\right.}$ | Mauricio \\ López Gómez ${ }^{(1)} 2^{*}$
}

${ }^{1}$ Universidad ECCl, Bogotá, Colombia

${ }^{2}$ FAC Fuerza Aérea Colombiana

Correspondence

William Evelio Rodríguez Delgado, Universidad ECCl, Bogota, Colombia

Email: wrodriguezd@ecci.edu.co

Copyright : Licencia de Creative Commons Reconocimiento-NoComercial 4.0 Interna.

\section{@creative}

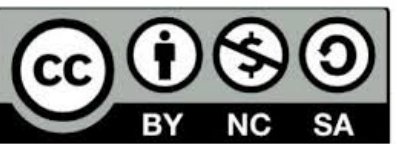

The publication of this journal is funded by Universidad ECCI, Bogotá-Colombia.

Editors: Luz Adriana Suáres Suáres, Germán Chaparro Molano, Robert Salazar

How to cite

Rodrígez W. et al., Life Cycle Analysis of Biodiesel Blends for Aviation, TECCIENCIA, Vol. 14, No. 27, 53-59, 2019

DOI:http://dx.doi.org/10.18180/tecciencia.2019.27.6
ABSTRACT. In the aviation sector, the use of biofuels has increased worldwide, therefore, this study assesses the environmental impact of these mass-based blends, named BKO, BK10, BK20 and BK30, according to their composition (Biodiesel + Kerosene) and the percentage of mass fraction. The study uses life cycle analysis with the SimaPro software and the Ecoinvent database for Colombia. The stages of cultivation, oil extraction and refining were established for biodiesel, while for the kerosene the stages defined were crude oil extraction and its refining. Results show that the stage with the greatest impact is the cultivation and extraction for both the category of freshwater ecotoxicity, acidification and terrestrial eutrophication.

keywords: Biodiesel, Freshwater Ecotoxicity, Acidification, Terrestrial Eutrophication, Life Cycle.

RESUMEN. En el sector de la aviación, el uso de biocombustibles se ha incrementado a nivel mundial, por lo tanto, se evaluará el impacto ambiental de estas mezclas con base másica, llamadas BKO, BK10, BK20 y BK30 de acuerdo con su composición (Biodiesel + queroseno) y con el porcentaje de fracción másica presente. El estudio utiliza análisis de ciclo de vida con el software SimaPro y la base de datos Ecoinvent para Colombia. Se establecieron para el biodiesel las etapas de cultivo, extracción de aceite y refinación, para el queroseno se definieron las etapas de extracción del crudo y su refinación. Se evidencia que la etapa que mayor presenta impacto es el cultivo y la extracción tanto para la categoría de ecotoxicidad de agua dulce, acidificación y eutrofización terrestre.

Palabras clave: biodiesel, ecotoxicidad de agua dulce, acidificación, eutrofización terrestre, ciclo de vida.

\section{1 | INTRODUCTION}

Aviation emits $820 \mathrm{~T}$ of $\mathrm{CO}_{2}$ per year, which correspond to $2.5 \%$ of global emissions, and only $5 \%$ of commercial aviation uses alternative fuels $[1,2,3,4,5,6]$. Therefore, th use energy from neutral or negative coal is vital, as more air traffic is expected in the upcoming years. Currently, projects and tests with biofuels are being carried out for the aviation industry, mainly in Russia, the United States and Brazil [7] [8]. Globally, biofuel production is derived from agricultural crops, especially sugarcane [9].

\footnotetext{
*Equally contributing authors.
} 
Different companies worldwide are producing and marketing worldwide the bio-biokerosene, such as Agrisoma Biosciences, SG Biofuels, AltAir Fuels, Amyris, Gevo, Virent, Petrobras, Neste Oil and Rentech. However, in Colombia no biokerosene is produced commercially and the main biofuels produced in the country are ethanol or fuel alcohol and biodiesel [10].

In Colombia, $87 \%$ of biodiesel production is made using African palm. Biodiesel has also been obtained from fig seeds and other raw materials such as sunflower, soy and rapeseed oils, and animal fats [10]. Despite the waste problem generating acids that are more difficult to treat in the transesterification stage (Sajid \& Khan, 2016), Colombia ranks 13th worldwide and 3rd in South America with a production of 8500 barrels per day. Even though the study of other energy sources in various systems has been the focus of many studies $[11,12,13,14,15]$, the use of biomass remains attractive.

Currently, blends of kerosene with biodiesel are being used as alternative fuels for the aviation sector, although it is critical to consider the viscosity of the blend, the freezing point, melting point, boiling point and miscibility in these blends [16].

Life cycle analysis covers all the processes of a product, from the extraction of materials, conversion, resources and final disposal. It is based on the standard NTC-ISO14040, which defines the methodology, analysis and calculation of impact. Some studies have been developed in the aviation sector using life cycle analysis.

Life cycle analysis aims to determine the environmental impact of palm oil biodiesel, using different impact categories such as climate change and ozone depletion. Some authors have found that the greatest impact is on the category of climate change in the stages of transesterification due to the consumption of energy and materials [17]. Other studies have also found impacts at this stage [18]. A research using the Ecoinvent database and the global warming and accumulated energy potential method found that the use of biodiesel decreases emissions by $85 \%$ [19]. However, studies on biodiesel production have proved that one of the greatest impacts is in the use of fertilizers at the crop stage [20].

This research evaluates the environmental impact of the production of biodiesel from different blends of JET A1 BK10, BK20, BK30, BK100 and BKO in the stages of cultivation, extraction, esterification, refining and extraction of oil through a life cycle analysis using Scimapro ${ }^{\circledR}$ software to model the stages of the process. The impact categories with the highest values were considered, such as acidification, freshwater ecotoxicity, terrestrial eutrophication, land use, and water use. Unlike other studies found, this research evaluates more categories in order to have a wider spectrum of impacts.

\section{2 | MATERIAL AND METHODS}

\subsection{Fuel blends}

Four types of blends were used for each work run in the bench tests of the PT6 engine. As nomenclature for the research work, the mass-based blends of kerosene and biodiesel fuels will be identified as BK \#, where:

$\mathrm{B}$ represents biodiesel as secondary fuel $\mathrm{K}$ represents kerosene, which is the primary fuel, and finally \# represents the percentage of mass fraction of biodiesel that is in the blend.

The current study evaluates blends BKO, BK10, BK20 and BK30.

\section{2 | Impact assesment}

To assess several impact categories, the method used was ILCD 2011 Midpoint + V1.10 / EC-JRC Global, equal weighting, which is incorporated into SimaPro ${ }^{\circledR}$. For this study, the categories used are climate change, acidification, land use, water use, ionizing radiation, eutrophication and fresh water.

The Ecoinvent $v 3$ database was selected to take information about the production of biodiesel and kerosene Jet A-1 at their different stages from cultivation and transport of the crop to oil extraction and refining. 


\section{3 | Material balance}

A review of the biodiesel production stages was made from documents, field lists and research articles. Specific characteristics and data of the process were determined such as energy and cultivated areas. Data of Colombian research were reviewed, but also from other countries where it was necessary to deduce some data, based on the available information.

Mass balance systems were calculated taking into account the production of $1 \mathrm{~kg}$ of biodiesel to determine the associated impact. Fig. 1 shows a general scheme of biodiesel production at its three stages, with its main inputs and outputs. Biodiesel production begins with the cultivation stage. At this stage, the soil is adapted, and fertilizers are applied. Then, in the oil extraction stage, fruits are transported from the crop to a plant where sterilization and smoothing processes are used to facilitate their extraction. In this phase, all organic waste is removed and the generated waste is sent to processes of treatment.

Transterification is the process where a reaction takes place between palm oil and an alcohol, which can be methanol or ethanol, in the presence of a catalyst that can be sodium hydroxide $(\mathrm{NaOH})$ or potassium hydroxide $(\mathrm{KOH})$. The reaction yields as product the alkyl esters, which constitute the so-called biodiesel and glycerin [9]. After this process, the biodiesel is separated from the glycerin and purified by different methods [8].

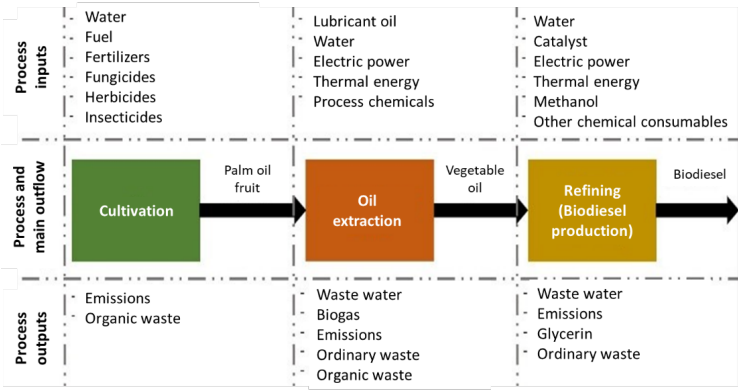

FIG. 1 Biodiesel Matter Balance.

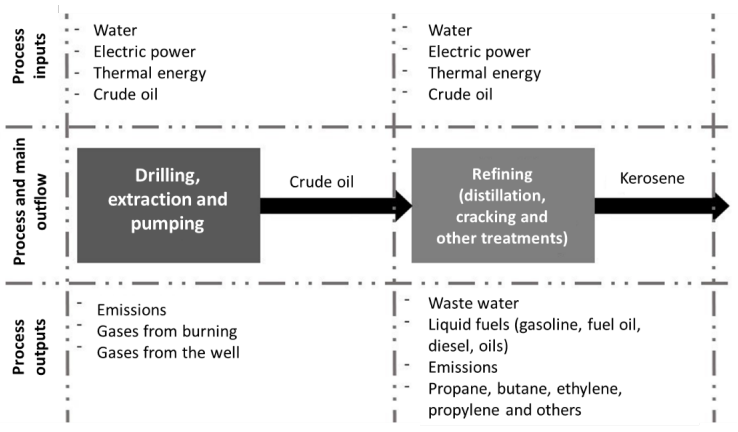

FIG. 2 Biodiesel Matter Balance

Fig. 2 shows the production of kerosene, which begins with the extraction of oil from the well. Then, the oil is taken to a refining plant where it enters a desalination process where the salt of the crude oil is removed. Subsequently, the crude oil is heated by a heat exchanger and enters a distillation tower.

The second fraction, which is approximately $33 \%$ of the crude oil input, is the raw material for the production of aviation fuels. This fraction is further processed in a hydrotreator to become kerosene and special solvents, followed by the fraction called "fuel oil" or "medium distilled base oil" that includes diesel and heating fuel.

Kerosene is generated as a direct fraction of distilled crude oil at a boiling point that varies from $205^{\circ} \mathrm{C}$ to $260^{\circ} \mathrm{C}$. The input data for the simulation were calculated based on the production of $1 \mathrm{~kg}$ of kerosene.

Once each production process has been modeled and included independently of kerosene and biodiesel, the results of the different impact categories of each fuel are analyzed to verify its impact by mixing the mass proportions $\mathrm{BKO}, \mathrm{BK} 10, \mathrm{BK} 20$ and $\mathrm{BK} 30$

\section{4 | Result and Discussion}

With the life cycle analysis, not only the environmental impact is established, but also information on the impact can be obtained in three fronts, therefore, the damage to the availability of resources is assessed in the following categories: water resource depletion, freshwater ecotoxicity and land use. Regarding damage to the ecosystem, the categories analyzed are terrestrial eutrophication and acidification. Finally, in health damage, the category is climate change.

In the impact category of freshwater ecotoxicity, Fig. 3 shows that for the BK100 blend, a high value of 
$(0.72 \%$ CTUe) is presented in the cultivation stage, which is due to the amount of fertilizers such as phosphate monoammonic $\mathrm{N}$ and $\mathrm{P}$, and triple superphosphate. According to inventory data from studies for palm oil [21], fertilizers contain toxic elements that pollute the water. At this stage, as the blend decreases, the impact also decreases from values of BK30 $(0.50 \%$ CTUe) to BK10 (0.05\% CTUe), since less palm kernels are cultivated. In the transesterification stage, a similar behavior to that of the cultivation stage is presented, as the blend also increases the impact. The reason is that additives, such as methanol and sodium hydroxide, are required to produce biodiesel, which generates liquid waste in BK 100 (0.16\% CTUe ), BK 30 (0.11\% CTUe) and BK20 (0.09\% CTUe). For oil extraction, the values are BKO ( $0.75 \%$ CTUe) and BK30 (0.23\% CTUe), that is, when more oil is extracted, the impact increases, since the extraction processes affect water sources.

Fig. 4 shows the impacts for the water resource depletion category. The greatest impacts for this category are during cultivation ( $1 \% \mathrm{~m} 3$ water eq for the $\mathrm{BK} 100 \mathrm{blend}$ ), due to the high consumption for the cultivation of these plantations, and in the extraction stage $(0.34 \% \mathrm{~m} 3$ water eq for all blends), due to the smoothing and sterilization processes. In the transesterification stage, there are no impacts on water since its impact is more associated with the use of catalysts and chemicals for the reaction. In the refining stage, a large amount of water is consumed for desalination, vapor extraction and fractionation processes of crude oil.

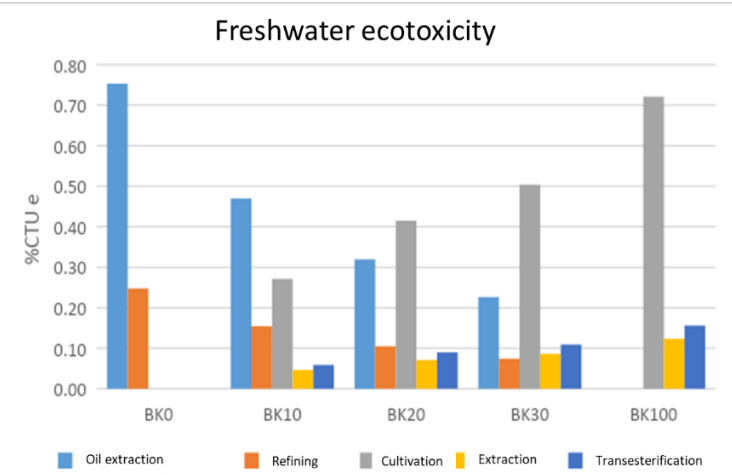

FIG. 3 Freshwater ecotoxicity.

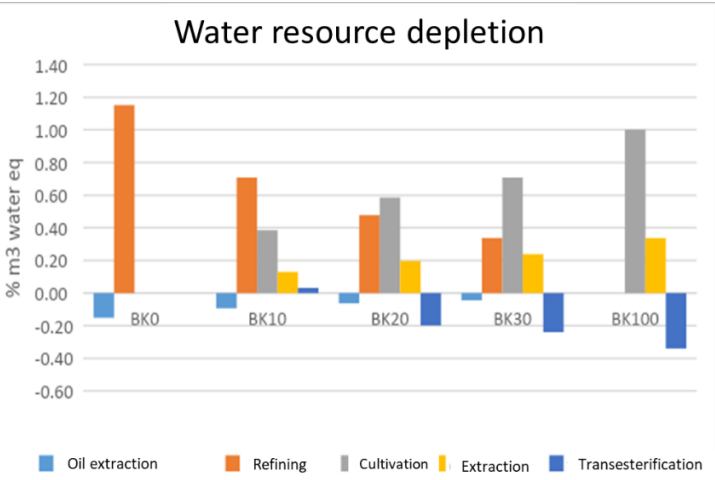

FIG. 4 Water resource depletion.

Fig. 5 corresponds to the category of land use. The impacts of oil extraction are observed with values between in $\mathrm{BK} 20$ of $8.22 \% \mathrm{KgC}$ deficit and in $\mathrm{BK} 10$ of $2 \% \mathrm{KgC}$ deficit. This can be due to the impact of extracting oil from the soil, since soil properties are affected by the processes to open it and remove the oil.

According to the land use category, at the cultivation stage this type of technologies has a positive impact since this type of palm kernel crops can improve the local economy and avoid other impacts to the soil by mining, oil extraction and construction. Currently, the land use is changing to palm oil crops, which have increased between 40 and 60\% [19] in the country. As shown in Fig. 5, there is no negative impact in this aspect, except for the stage of oil extraction.

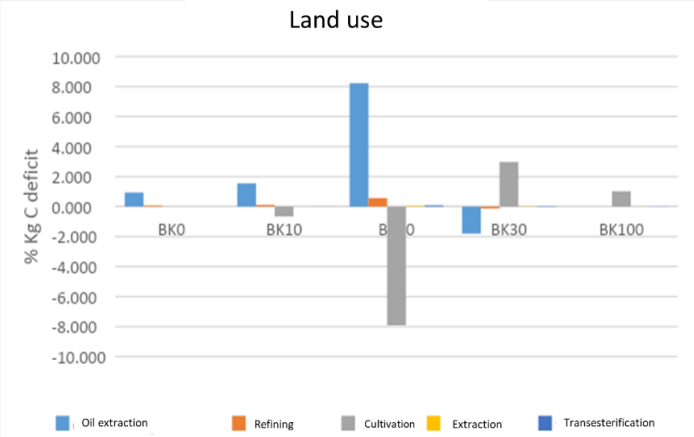

FIG. 5 Land use.

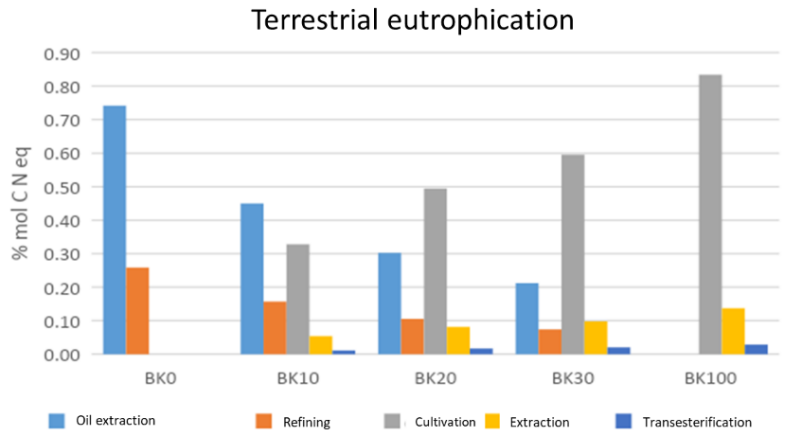

FIG. 6 Terrestrial eutrophication. 
Fig. 6 shows the impacts on the terrestrial eutrophication category. As in the freshwater ecotoxicity, the greatest impacts are at the cultivation stage. The higher the blend is, the higher the impact: the blend of BK100 has a value of $0.80 \%$ molc $\mathrm{N}$ eq, while the lowest blend (BK10) has a value of $0.33 \%$ molc $\mathrm{N}$ eq, which indicates a considerable decrease. As reported in other studies [22], this can be due to the presence of nitrogen in most fertilizers, which causes eutrophication to water and soil. In the extraction stage, there are also impacts especially for the blend of BK100 (0.14\% molc $\mathrm{N}$ eq). Low values of BK $10(0.05 \% \mathrm{molc} \mathrm{N}$ eq) are observed in this stage. In the oil extraction stage, there are low values between BKO $(0.26 \%$ molc $\mathrm{N} \mathrm{eq})$ and BK30 (0.07\% molc $\mathrm{N}$ eq), since no chemicals are used.

In the category of acidification, Fig. 7 shows that the highest values are still present in the cultivation stage for BK $100(0.83 \%$ molc $\mathrm{H}+$ eq) and for blends of BK10 $(0.13 \%$ molc $\mathrm{H}+$ eq). Unlike the other categories of impact, in the oil extraction stage, the impact increases as the blend decrease, since at this stage impacts are generated by the oil, gas and sediments that affect the soil (BKO $0.63 \%$ and $\mathrm{BK} 300.13 \%$ molc $\mathrm{H}+\mathrm{eq}$ ). In the refining stage, the impact values are similar (BKO $0.37 \%$ and $\mathrm{BK} 300.22 \% \mathrm{molc} \mathrm{H}+$ eq), due to the chemicals used for Kerosene production. These results contrast with the literature found, where high values are around 95\% for this category of impact in Colombia, particularly at the production stage [17]. At the level of LCA studies, the greatest impacts are presented in this category [20]. The challenge of the use of biofuels is not only associated with their production, but with everything that involves their obtention, including cultivation techniques, irrigation method, type and origin of fertilizers, rotation time of plants in the crop. All these factors can affect the ecosystem and change its properties. In the case of soil macronutrients (carbon, calcium and magnesium), they must be preserved. Fig. 8 shows the results of the climate change category, where the greatest impact occurs in the cultivation stage for $\mathrm{BK} 2 \mathrm{O}\left(26.18 \% \mathrm{Kg} \mathrm{CO} 2\right.$ eq), due to the release of $\mathrm{CO}_{2}$ into the atmosphere. With a lower blend, it has less impact $(\mathrm{Bk} 10=-1.68 \% \mathrm{Kg} \mathrm{CO}$ eq). At the other stages, there is a significant impact, although it decreases in the cultivation stage, as $\mathrm{CO}_{2}$ is retained in the process of photosynthesis in the plantations. Brazil produces energy from waste rather than from plantations, therefore it has fewer impacts at the cultivation stage [23]. In contrast, Colombia uses many fertilizers to obtain biofuels, as shown by the category of acidification and eutrophication, which represents a great impact at the cultivation stage.

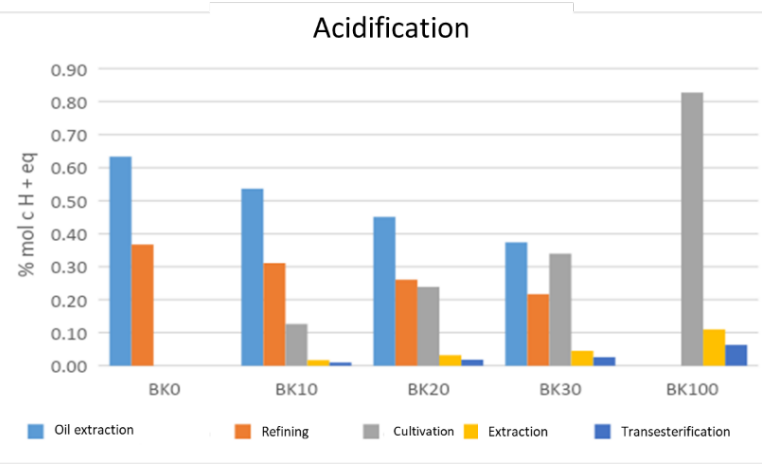

FIG. 7 Acidification.

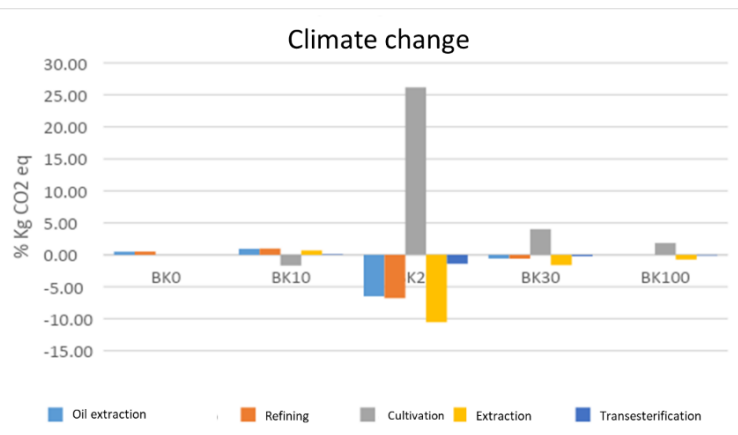

FIG. 8 Climate change.

As explained before, one of the biggest impacts of the use of biofuel blends is in the cultivation stage, because the oil palm needs herbicides and fertilizers to avoid weeds growing around these plants. This has been reported in other studies (citation to comparison). In consequence, other plants such as jatropha, higuerilla, sunflower seeds [20] and higuerilla Brasil, or even residues have also been targeted.

It is worth noting that each type of plant has its own advantages and disadvantages. For example, although jatropha needs no herbicides at the cultivation stage, it requires further processing in the transesterification stage. For this reason therefore, crops to produce biodiesel must be diversified, as suggested by César, Batalha, and Zopelari (2013). In the case of palm oil, these crops could be alternated with plants that provide nutrients such as nitrogen, and also rotate the crops to avoid soil degradation. 
It is imperative to improve the methods of cultivation and the use of fertilizers, because studies agree that the techniques are linked to the impact. There are still many fertilizers that are imported, for example, Brazil imports $50 \%$ of the phosphate and $90 \%$ of the nitrogen [23], therefore the impacts are not only on the crop, but also on the air due to the emissions when transporting them. Researchers must look for biodegradable fertilizers with less impact on the soil, and evaluate the potential of each zone and the types of plants for the production of biofuels. It should also be noted that the extraction stage has a significant impact, therefore, different conversion alternatives to transesterification should be developed. Other alternatives that have been proposed are microwaves and ultrasound [18], the use of chemicals such as methanol and sodium hydroxide, or strategies that allow the reuse of waste material. In this study, different impact categories are assessed from those that are most commonly used such as land use and climate change. For example, water ecotoxicity and water resource depletion have been scarcely implemented. These categories give a broader overview, in addition to show the effects focused on the water resource.

\section{3 | CONCLUSIONS}

The stage of cultivation is the one with the greatest impact according to the categories of impact of acidification, terrestrial eutrophication, and freshwater ecotoxicity. Therefore, inputs or fertilizers and agronomic techniques for crops should be reviewed.

At the ecosystem level, there are significant impacts on the soil, since it is acidified, which can lead to property losses, and therefore, the need of fertilizers. At the level of resource availability, water can be affected since large quantities are demanded, both for the cultivation processes and for the extraction of oil.

Since increasingly more areas are dedicated to the cultivation of oil palm, this type of studies should be widely performed in order to determine the impacts and take measures of impact mitigation at each of its stages.

\section{References}

[1] U. Neuling and M. Kaltschmitt, "Techno-economic and environmental analysis of aviation biofuels," Fuel Processing Technology, vol. 171, pp. 54-69, 2018. doi: 10.1016/j f fuproc. 2017.09.022

[2] M. A. M. Betancourt and W. M. Naranjo, "Aprovechamiento integral del glicerol residual en la industria del biodiesel: caso 1, 3-propanodiol (1, 3-pd)," TECCIENCIA, vol. 6, no. 12, pp. 80-93, 2012. http:// tecciencia.ecci.edu.co/index.php/TECCIENCIA/article/view/50.

[3] A. E. D. Tobón, W. A. Chaparro, and J. A. P. Plazas, "Comparison of the behavior of biofuel based on castor and sunflower oils," Tecciencia, vol. 7, no. 14, pp. 54-60, 2013. doi: 10.18180/tecciencia.2013.14.7

[4] J. D. Arévalo, Á. Martinez-Hernández, J. C. Vargas, and L. F. Córdoba, "Hydrogen production and purification by bioethanol steam reforming and preferential oxidation of co," Tecciencia, vol. 13, no. 25, pp. 55-64, 2018. doi: 10.18180/tecciencia.2018.25.7

[5] F. E. Sierra-Vargas, M. A. Montenegro, and F. O. Narváez Argoty, "Incidence of using chicken fat based biodiesel on the performance of a $13.5 \mathrm{kw}$ compression ignition piston engine for power generation," Tecciencia, vol. 10, no. 19, pp.61-72, 2015. doi: 10.18180/tecciencia.2015.19.9,http://tecciencia. ecci.edu.co/index.php/TECCIENCIA/article/view/253/pdf_47.

[6] F. E. S. Vargas, M. A. M. Mier, and F. Narváez, "Incidence of using chicken fat based biodiesel on the performance of a 13.5 kwe compression ignition piston engine for power generation," TECCIENCIA, vol. 10, no. 19 , pp. 61-72, 2015. doi: 10.18180/tecciencia.2015.19.9

[7] A. da Silva César, M. O. Batalha, and A. L. M. S. Zopelari, "Oil palm biodiesel: Brazil's main challenges," Energy, vol. 60, pp. 485-491, 2013. doi: 10.1016/j . energy . 2013.08.014 
[8] Z. Shi, B. Zhao, S. Tang, and X. Yang, "Hydrotreating lipids for aviation biofuels derived from extraction of wet and dry algae," Journal of cleaner production, vol. 204, pp. 906-915, 2018. doi: 10.1016/j . jclepro. 2018.08 .351

[9] C. Chuck, M. McManus, M. Allen, and S. Singh, "Feedstocks for aviation biofuels," in Biofuels for Aviation, pp. 17-34, Elsevier, 2016.

[10] C. A. C. Alzate, "Perspectivas de la producción de biocombustibles en colombia: contextos latinoamericano y mundial," Revista de ingeniería, no. 29, pp. 109-120, 2009.

[11] Y. Muñoz, O. Vargas, G. Pinilla, and J. Vásquez, "Sizing and study of the energy production of a grid-tied photovoltaic system using pvsyst software," Tecciencia, vol. 12, no. 22, pp. 27-32, 2017. doi: 10.18180/ tecciencia.2017.22.4

[12] Y. Muñoz, J. Guerrero, and A. Ospino, "Evaluation of a hybrid system of renewable electricity generation for a remote area of colombia using homer software," Tecciencia, vol. 9, no. 17, pp. 45-54, 2014. doi: 10 . 18180/tecciencia.2014.17.6

[13] A. Alarcón Villamil, J. E. Hortúa, and A. López, "Comparison of thermal solar collector technologies and their applications," Tecciencia, vol. 8, no. 15, pp. 27-35, 2013. doi: 10.18180/tecciencia.2013.15.3

[14] J. Bonilla, R. P. Salazar, and M. Mayorga, "Kinetic triplet of colombian sawmill wastes using thermogravimetric analysis," Heliyon, vol. 5, no. 10, p. e02723, 2019. doi: 10.1016/j .heliyon. 2019.e02723

[15] C. C. Mendoza, A. M. Quintero, F. Santamaria, et al., "Estimation of electric energy required by electric vehicles based on travelled distances in a residential zone," Tecciencia, vol. 11, no. 21, pp. 17-24, 2016. doi: 10.18180/tecciencia.2016.21.4

[16] R. W. Jenkins, M. Munro, S. Nash, and C. J. Chuck, "Potential renewable oxygenated biofuels for the aviation and road transport sectors," Fuel, vol. 103, pp. 593-599, 2013. doi: 10.1016/j fuel.2012.08. 019

[17] A. I. Vidal-Benavides, J. C. Quintero-Díaz, and I. Herrera-Orozco, "Life cycle analysis of biodiesel production from used vegetal oil," Dyna, vol. 84, no. 201, pp. 155-162, 2017. doi: 10.15446/dyna.v84n201. 54469

[18] N. Faleh, Z. Khila, Z. Wahada, M.-N. Pons, A. Houas, and N. Hajjaji, "Exergo-environmental life cycle assessment of biodiesel production from mutton tallow transesterification," Renewable Energy, vol. 127, pp. 74-83, 2018. doi: 10.1016/j.renene.2018.04.046

[19] R. Buitrago Tello et al., Evaluación de los efectos ambientales de la gasolina, diesel, biodiesel y etanol carburante en Colombia por medio del Análisis de Ciclo de Vida. PhD thesis, Universidad Nacional de Colombia, 2014.

[20] K. Siregar, A. H. Tambunan, A. K. Irwanto, S. S. Wirawan, and T. Araki, "A comparison of life cycle assessment on oil palm (elaeis guineensis jacq.) and physic nut (jatropha curcas linn.) as feedstock for biodiesel production in indonesia," Energy Procedia, vol. 65, pp. 170-179, 2015. doi: 10.1016/j . egypro. 2015.01. 054

[21] L. Panichelli, L. Trama, and A. Dauriat, "Análisis de ciclo de vida (acv) de la producción de biodiesel (b100) en argentina," Universidad de Buenos Aires. Buenos Aires, 2006.

[22] H. Stichnothe and F. Schuchardt, "Life cycle assessment of two palm oil production systems," Biomass and bioenergy, vol. 35, no. 9, pp. 3976-3984, 2011. doi: 10.1016/j . biombioe.2011.06.001

[23] A. Queiroz, L. França, and M. Ponte, "The life cycle assessment of biodiesel from palm oil ("dendê") in the amazon," Biomass and bioenergy, vol. 36, pp. 50-59, 2012. doi: 10.1016/j . biombioe . 2011 .10.007 
